\title{
Inventory and distribution of the rodents in Aurès Mountains and Ziban oasis (Northeast of Algeria)
}

\author{
Hakim Drouai ${ }^{1}$, Mohammed Belhamra ${ }^{1}$ \& Fateh Mimeche ${ }^{2}$ \\ 1 Department of Agricultural Sciences, University of Biskra, BP 145 RP, 07000 Biskra, Algeria.. \\ 2 Department of Agricultural Sciences, University of M'Sila, BP 166 Echbilia, 28000 M'Sila, Algeria.
}

Correspondence

H. Drouai

E-mail: hakimdrouai@gmail.com

Received: 12 September 2017

Accepted: 19 February 2018

Published on-line: 16 March 2018

\section{Resumen}

Inventario y distribución de los roedores de las Montañas Aurès y el oasis de Ziban (noreste de Argelia)

Nuestro estudio muestra un inventario de roedores del noroeste de Argelia. Tas especies se capturaron en dos regiones: Taouziant (Montañas Aurès ) y Bouchagroune (oasis de Ziban). El periodo de muestreo duró diez mees en cada lugar: en Taouziant de febrero a nobiembre de 2014 y en Bouchagroune de septiembre de 2013 a junio de 2014. El método de trampeo en línea fue llevado a cabo mediante 40 jaulas-trampas instaladas en las regiones de estudio. Se capturaron ocho especies, que pertenecen a tres subfamilias y seis géneros. Tres especies se distribuyen en las dos regiones Rattus rattus, Mus musculus y Gerbillus amoenus. Tres especies se capturaron en los campos de cereal de Taouziant ( Rattus norvegicus, Meriones shawii y Jaculus jaculus) y dos especies en el palmeral de Bouchagroune (Psammomys obesus y Gerbillus gerbillus).

Palabras clave: Inventario, Roedores, Trampeo, Taouziant, Bouchagroune, Argelia.

\begin{abstract}
Our study presents an inventory of rodents in Northeast of Algeria. The species were captured at two regions: Taouziant (Aurès Montain) and Bouchagroune (Ziban oasis). The sampling period takes ten months at each site: in Taouziant between February to November 2014 and in Bouchagroune, from September 2013 to June 2014. The method of trapping online was performed using 40 wire traps installed at the studied regions. Eight species were captured. They belong to three subfamilies and six genera. Three species occur in the two regions: Rattus rattus, Mus musculus and Gerbillus amoenus. Three species were captured in Taouziant cereal fields ( Rattus norvegicus, Meriones shawii and Jaculus jaculus) and two species were found in Bouchagroune palm grove (Psammomys obesus and Gerbillus gerbillus).
\end{abstract}

Key words: Inventory, rodents, trapping, Taouziant, Bouchagroune, Algeria. 


\section{Introduction}

Rodents have a natural geographic distribution that covers the whole world and occupy all types of environments and they represent more than $40 \%$ of mammals diversity.

Most African rodents are herbivorous-granivorous and some of them can cause significant crop damage (Hubert 1984; Granjon \& Duplantier 2009). By destroying crops or modifying the soil by their burrowing systems and galleries, they are considered as pests (Singleton et al. 1999, 2003).

Some of these species are responsible for health problems for humans and domestic animals because they act as reservoirs of various pathogens, which they transmit directly or indirectly to humans such as cutaneous leishmaniasis in several regions in Algeria (Boudrissa et al. 2012 and Cherif et al. 2012). Bitam et al. (2008) detected the species Bartonella spp in different rodents, this bacterium is the causative agent of Bartonellosis disease. Enzootic plague has been reported by Malek et al. (2015). The prevalence of rickettsioses in febrile exanthemas in eastern Algeria is examined by Mokrani et al. (2012). Benredjem et al. (2014) investigate Lyme disease and tickborne rickettsioses transmitted by Ixodes ricinus ticks in northeastern Algeria.

Among the previous works carried out on rodents inventories in Algeria we quote: Kowalski \& Rzebik-Kowalska (1991), Belabbas \& Butet (1994), Hamdine (2000) and Hamdine et al. (2006), Khammes et al. (2006) and Khammes \& Aulagnier (2007). More recently, the works of Adamou-Djerbaoui et al. (2010, 2011, 2013, 2015), Bachar \& Belhamra (2012), Souttou et al. (2012), Beddiaf et al. (2013) and Hadjoudj et al. (2015). Despite all these works large areas of the country still remain to be prospected.

Our work aims at an inventory of rodents in two poorly known regions. The first is located in semi-arid region of the Aurès Mountains: Taouziant region (Khenchela Department, that was never explored for such purpose. The second is located in arid region of the Ziban: Bouchagroune region (Biskra Departement).

\section{Material and methods}

\section{Study area}

The study was carried out in two geographically and climatically different regions (Fig. 1).

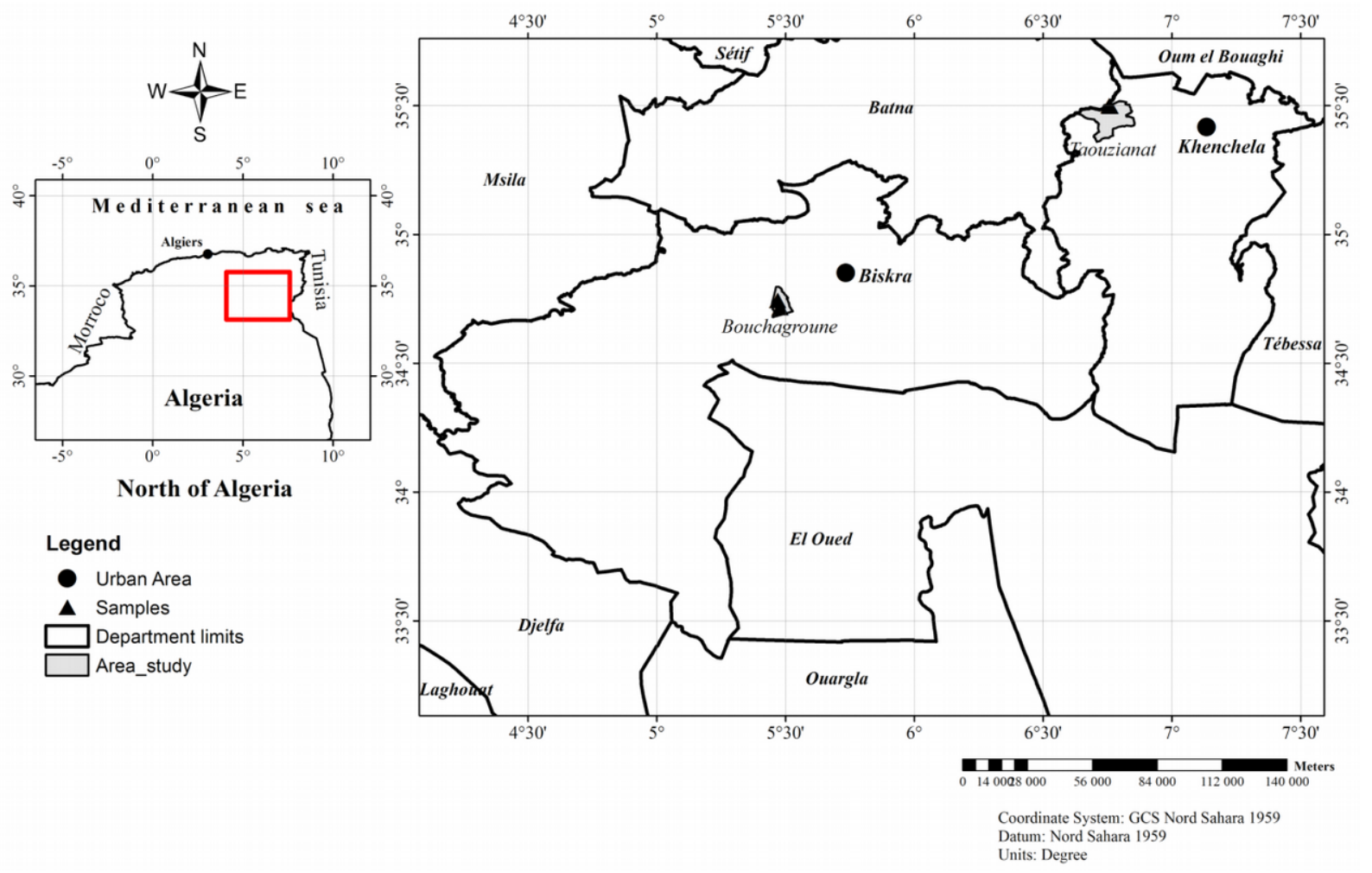

Figura 1. Áreas de estudio: localidades de Taouziant y Bouchagroune.

Figure 1. Study areas: Taouziant and Bouchagroune localities. 


\begin{tabular}{|c|c|c|c|c|c|}
\hline Departement & Locality & Geographical cooro & lates & Exploration period & Habitat specificities \\
\hline Khenchela & Taouziant & $35^{\circ} 29^{\prime} 52.8^{\prime \prime} \mathrm{N} \mathrm{6} 45^{\prime} 34.3^{\prime \prime E}$ & 968 MASL & February to November 2014 & Cereal fields and peripheral zone \\
\hline Biskra & Bouchagroune & $34^{\circ} 42^{\prime} 56.8^{\prime \prime} 5^{\circ} 28^{\prime} 40.8^{\prime \prime} \mathrm{E}$ & 132 MASL & September 2013 to June 2014 & $\begin{array}{c}\text { Palm grove, dates storage area and } \\
\text { peripheral zone }\end{array}$ \\
\hline
\end{tabular}

Tabla 1. Localidades encuestadas en el área de estudio, coordenadas geográficas, período de exploración y especificidades del hábitat Table 1. Localities surveyed in the study area, geographical coordinates, exploration period and habitat specificities

The Khenchela region, located in the Southeast of Constantine at the foothill of the Aurès Mountains, shows agricultural and natural landscapes. The average maximum temperature, 34.9 ${ }^{\circ} \mathrm{C}$, occurs in July and the minimum is in January, $1.85{ }^{\circ} \mathrm{C}$. The annual precipitation is $508.83 \mathrm{~mm}$. This region is classified in the semi-arid climatic zone. The trapping station is located at $4 \mathrm{~km}$ to the west of the city of Taouziant (Table 1). The traps are deposited in the agricultural fields (cereals: barley, durum wheat and soft wheat) and in the peripherals (pastoral zone) which counts several plant species among which Artemisia herba-alba Asso, Ziziphus lotus (L.) Lam. and Retama raetam (Forssk.) Webb \& Berthel.

The region of Biskra, known as Ziban, is an oasis. It is located at the Southern foothills of the Saharan Atlas. Its northern limit is made up of high mountains that attenuate the extension of the influences of the humid Mediterranean climate and gives the region an arid character towards the Sahara in the south.

The region of Biskra, known as Ziban, is an oasis. It is located on the southern foothills of the Saharan Atlas. Its northern limit is made up of high mountains that attenuate the extension of the influences of the humid Mediterranean climate and gives the region an arid character towards the Sahara in the south. The average maximum temperature is observed in August with $41.38^{\circ} \mathrm{C}$, the minimum during January with $8.26^{\circ} \mathrm{C}$. Precipitation during the study period is $125.4 \mathrm{~mm}$, while in the ten years (2004-2014) it is $128 \mathrm{~mm}$. The trapping station is located in the commune of Bouchagroune (Table 1). The traps are deposited in the palm grove, dates storage zone and in the peripherals (steppe zone). It is covered by several species of plants: Macrochloa tenacissima (L.) Kunth, Atriplex halimus L., A. herba-alba.

\section{Sampling}

During 10 months: from February to November 2014 in Taouziant and September 2013 to June 2014 in Bouchagroune (Table 1) we performed trapping sessions in these two localities. The plots in the study sites were chosen based on indices of presence of rodents (active burrows, droppings, etc.) and according to the arrangement plots in relation with roads access and the presence of an officer surveillance.

In our inventory, we used 40 wire traps in each site, the mousetrap is BTS type (Besançon Technique Service, France) with the following measures; length: $30 \mathrm{~cm}$, width $14 \mathrm{~cm}$, height $12 \mathrm{~cm}$ ). They were placed for three consecutive nights on two $100 \mathrm{~m}$ lines and spaced $35 \mathrm{~m}$ apart. The space between the mousetraps of each line was $05 \mathrm{~m}$ (Avenant \& Cavallini 2007; Adamou-Djerbaoui et al. 2015).

Each month, the baited mousetrap were installed in the afternoon and left for three consecutive nights and were collected every morning (Adamou-Djerbaoui et al. 2015, Dupuy et al. 2007). The total number of trap nights in the two study regions was 2400 trap nights:

2400 trap nights $=[40$ mousetraps $\times 2$ sites $\times(3$ nights / month)] x 10 months

The traps were baited by the sheep grease or bread with tuna and dates (Zaime \& Pascal 1988, Denys et al. 2015).

Each live captured specimen was placed in a labelled box in order to determine the species and to avoid possible contamination of zoonoses in these micromammals.

\section{Trapping Effort, Abundance Index (IA)}

Trapping effort is the number of rodents caught / 100 trap nights (Avenant \& Cavallini 2007). According to Hamdine (2000), the index of abundance "success of trapping" is given by the following formula:

$$
\mathrm{IA}=\mathrm{Ni} /(\mathrm{NNT}) \times 100
$$

Ni: Number of specimens caught for different species; NNT: Number of night-traps $=$ number of nights $\mathrm{x}$ number of traps.

\section{Analysis of rodent fauna}

The alived captured specimens were carried to the laboratory and euthanized. Each specimen was weighted (body mass in g) and the standard exter- 
nal measurements recorded: body length with head $(\mathrm{BH})$, length of tail $(\mathrm{T})$, hind foot length (HF) and ear length (E) were also taken in $\mathrm{mm}$. The determination was made using the identification keys of Bernard (1970), Aulagnier \& Thevenot (1986), Granjon \& Duplantier (2009) and Couzi (2011).

\section{Species abundance, species diversity and community composition \& structure}

To evaluate the species abundance, species diversity and the differences in community composition and structure at each site, data were analyzed using PAST software (Paleontological Statistics; Version 2.17). The indexes used to examine rodent community were: species richness (S), relative abundance (RA), dominance (D), Shannon diversity index $(H)$, Simpson Diversity index (1-D) and evenness (E). These indices are useful for a comparison between populations of two geographically distant regions.

\section{Results}

\section{Trapping success}

We obtained 142 rodents for a total of 2400 nights, which represents a trapping success of $5.91 \%$. The success of trapping varies from $3.33 \%$ in the Taouziant and $2.58 \%$ in the Bouchagroune (Table 2).

\section{Rodent fauna}

Among the 142 rodent specimens collected we found a diversity of 8 species from 6 genera and tree subfamilies: Murinae, Gerbillinae and Dipodinae (Table 3).

Murinae were the most frequently collected and included three species representing two genera accounting for $50.70 \%$ of the total number captured. Gerbillinae were represented by four species including three genera and represented

\begin{tabular}{|c|c|c|c|}
\multicolumn{1}{c}{ Locality } & \multicolumn{1}{c}{ TN } & NC & NC /TN \% \\
\hline Taouziant (Cereal fields) & 2400 & 80 & $\mathbf{3 . 3 3}$ \\
\hline Bouchagroune (Palme grove) & 2400 & 62 & $\mathbf{2 . 5 8}$ \\
\hline Both regions & 4800 & 142 & $\mathbf{5 . 9 1}$ \\
\hline
\end{tabular}

Tabla 2. Esfuerzo de captura por localidad. TN: noches de trampeo; NC: número de capturas; $\mathrm{NC} / \mathrm{TN}$ : tasa de éxito de captura, en porcentaje.

Table 2. Trapping effort per locality. TN: trap nights; NC: number of captures; Ratio NC/TN: trapping success in percentage.
$34.51 \%$ of the total. The Dipodinae are represented by a single taxon which reaches $14.79 \%$ of the total rodent captured.

The number of the captured species was almost different at both sites: 6 at cereal fields of Taouziant and 5 at palm grove of Bouchagroune (Table 3). Three species were found at both sites (Black rat Rattus rattus (L., 1758), House mouse Mus musculus L., 1758 and Pleasant Gerbil Gerbillus amoenus (de Winton, 1902)), three other species were found only at cereal fields of Taouziant locality (Brown rat Rattus norvegicus (Berkenhout, 1769), Shaw's Jird Meriones shawii (Duvernoy, 1842) and Lesser Egyptian jerboa Jaculus jaculus (L., 1758)) and two supplementary species were captured only at palm grove of Bouchagroune locality (Sand Rats Psammomys obesus Cretzschmar, 1828 and Lesser Egyptian gerbil Gerbillus gerbillus (Olivier, 1801)).

In cereal fields of Taouziant locality, $R$. rattus and $J$. jaculus are the most abundant species, representing respectively $28.75 \%$ and $26.25 \%$. $P$. obesus is the most abundant species in the palm grove of Bouchagroune locality with $35.48 \%, R$. rattus and $M$. musculus followed in that order with $27.42 \%$ and $17.74 \%$ respectively.

The physical features are shown in the table 4 .

\section{Species diversity}

The diversity indexes and the evenness of rodents captured in the two localities studied (Table 5) showed that the index of dominance (D) varies from 0 to 1 . Its values in our study were 0.21 vs 0.25 . They are related respectively to cereal fields of Taouziant and palm grove of Bouchagroune localities. However the Simpson Diversity Index (1D) shows 0.79 vs 0.75 in the same localities at the opposite of the dominance index, where $\mathrm{D}$ takes on values between zero and one, 1-D provides a proportional measure of diversity that is much less sensitive to species richness (Magurran 2004).

\begin{tabular}{|l|c|c|}
\multicolumn{1}{c}{} & $\begin{array}{c}\text { Taouziant } \\
\text { (Cereal fields) }\end{array}$ & $\begin{array}{c}\text { Bouchagroune } \\
\text { (Palme grove) }\end{array}$ \\
\hline Taxa (S) & 6 & 5 \\
\hline Individuals (N) & 80 & 62 \\
\hline Dominance (D) & 0,21 & 0,25 \\
\hline Simpson Diversity (1-D) & 0,79 & 0,75 \\
\hline Shannon (H) & 1,68 & 1,48 \\
\hline Evenness (E) & 0,89 & 0,88 \\
\hline
\end{tabular}

Tabla 5. Índices de diversidad y uniformidad de roedores para las dos localidades estudiadas.

Table 5. Diversity indexes and evenness of rodents for the two localities studied. 


\begin{tabular}{|c|c|c|c|c|c|}
\hline \multirow[b]{2}{*}{ Subfamilies } & \multirow[b]{2}{*}{ Species } & \multicolumn{2}{|c|}{ Taouziant } & \multicolumn{2}{|c|}{ Bouchagroune } \\
\hline & & $N$ & $R A \%$ & $N$ & $R A \%$ \\
\hline \multirow[t]{3}{*}{ Murinae } & Rattus rattus (L., 1758) & 23 & 28,75 & 17 & 27,42 \\
\hline & \begin{tabular}{|l|} 
Rattus norvegicus (Berkenhout, 1769) \\
\end{tabular} & 8 & 10,00 & 0 & $\mathbf{0}$ \\
\hline & Mus musculus L., 1758 & 13 & 16,25 & 11 & 17,74 \\
\hline \multirow[t]{4}{*}{ Gerbillinae } & Psammomys obesus Cretzschmar, 1828 & 0 & $\mathbf{0}$ & 22 & 35,48 \\
\hline & Meriones shawii (Duvernoy, 1842) & 9 & 11,25 & $\mathbf{0}$ & $\mathbf{0}$ \\
\hline & \begin{tabular}{|l} 
Gerbillus gerbillus (Olivier, 1801) \\
\end{tabular} & $\mathbf{0}$ & $\mathbf{0}$ & 7 & 11,29 \\
\hline & Gerbillus amoenus (de Winton, 1902) & 6 & 7,50 & 5 & 8,06 \\
\hline Dipodinae & Jaculus jaculus (Linnaeus, 1758) & 21 & 26,25 & $\mathbf{0}$ & 0 \\
\hline Total individuals & 142 & \multicolumn{2}{|l|}{80} & \multicolumn{2}{|l|}{62} \\
\hline Total richness & 8 & \multicolumn{2}{|c|}{6} & 5 & \\
\hline
\end{tabular}

Tabla 3. Especies de roedores recogidas. Número y abundancia relativa $(R A \%)$ en las localidades de Taouziant y Bouchagroune.

Table 3. Rodent species collected. Number and relative abundance $(R A \%)$ at Taouziant and Bouchagroune localities.

Cereal fields of Taouziant

\begin{tabular}{|c|c|c|c|c|c|c|}
\hline \multicolumn{2}{|l|}{ Rodents species } & Weights (g) & $\mathrm{BH}(\mathrm{mm})$ & $\mathrm{T}(\mathrm{mm})$ & $\mathrm{HF}(\mathrm{mm})$ & $E(\mathrm{~mm})$ \\
\hline \multirow{3}{*}{$\begin{array}{l}\text { Ratt rattus } \\
(n=23)\end{array}$} & Min & 45,68 & 111 & 121 & 27 & 18 \\
\hline & Max & 175,29 & 180,4 & 213 & 35 & 24,1 \\
\hline & Mean & 112,06 & 148,41 & 174,61 & 30,09 & 20,82 \\
\hline \multirow{3}{*}{$\begin{array}{l}\text { Jaculus jaculus } \\
(n=21)\end{array}$} & Min & 86,25 & 106 & 176 & 59,89 & 18,7 \\
\hline & Max & 141,6 & 126,8 & 227,4 & 70,7 & 24 \\
\hline & Mean & 117,55 & 118,65 & 213,09 & 66,5 & 21,94 \\
\hline \multirow{3}{*}{$\begin{array}{l}\text { Mus musculus } \\
(n=13)\end{array}$} & Min & 10,85 & 66 & 71 & 15,1 & 11,8 \\
\hline & Max & 26,2 & 89 & 99 & 18,3 & 14 \\
\hline & Mean & 17,32 & 78,63 & 86,13 & 16,05 & 12,7 \\
\hline \multirow{3}{*}{$\begin{array}{l}\text { Meriones shawii } \\
(\mathrm{n}=09)\end{array}$} & Min & 77,4 & 137,69 & 123,3 & 32,04 & 15,14 \\
\hline & Max & 151,39 & 171,28 & 151,16 & 36,37 & 19,28 \\
\hline & Mean & 109,13 & 157,6 & 141,5 & 33,56 & 16,96 \\
\hline \multirow{3}{*}{$\begin{array}{l}\text { Rattus norvegicus } \\
(\mathrm{n}=08)\end{array}$} & Min & 166,1 & 242 & 203 & 39,5 & 20,1 \\
\hline & Max & 212 & 266 & 209 & 42 & 21,6 \\
\hline & Mean & 185,05 & 252,04 & 206,03 & 40,74 & 20,66 \\
\hline \multirow{3}{*}{$\begin{array}{l}\text { Gerbillus amoenus } \\
(\mathrm{n}=06)\end{array}$} & Min & 14,14 & 71,75 & 105,09 & 21,09 & 11,17 \\
\hline & Max & 20,04 & 84,61 & 124,92 & 22,64 & 12,64 \\
\hline & Mean & 17,335 & 77,36 & 113,25 & 21,90 & 11,71 \\
\hline
\end{tabular}

Palm grove of Bouchagroune

\begin{tabular}{|c|c|c|c|c|c|c|}
\hline \multicolumn{2}{|l|}{ Rodents species } & Weights (g) & $\mathrm{BH}(\mathrm{mm})$ & $\mathrm{T}(\mathrm{mm})$ & $\mathrm{HF}(\mathrm{mm})$ & $E(\mathrm{~mm})$ \\
\hline \multirow{3}{*}{$\begin{array}{l}\text { Psammomys obesus } \\
(n=22)\end{array}$} & Min & 69,7 & 128,3 & 114,7 & 30,2 & 10,04 \\
\hline & Max & 172,1 & 136,2 & 128,4 & 34 & 12,4 \\
\hline & Mean & 102,9 & 132,36 & 119,45 & 31,62 & 11,28 \\
\hline \multirow{3}{*}{$\begin{array}{l}\text { Rattus rattus } \\
(\mathrm{n}=17)\end{array}$} & Min & 43,87 & 123,1 & 155 & 30,4 & 20,7 \\
\hline & Max & 209,3 & 192,8 & 236,1 & 38,6 & 29,8 \\
\hline & Mean & 131,11 & 162,29 & 205,5 & 34,24 & 25,91 \\
\hline \multirow{3}{*}{$\begin{array}{l}\text { Mu musculus } \\
(\mathrm{n}=11)\end{array}$} & Min & 10,3 & 69 & 71 & 15 & 11,9 \\
\hline & Max & 18,8 & 86 & 95 & 19,2 & 14 \\
\hline & Mean & 14,3 & 77,82 & 83,59 & 16,13 & 12,62 \\
\hline \multirow{3}{*}{$\begin{array}{l}\text { Gerbillus gerbillus } \\
(\mathrm{n}=07)\end{array}$} & Min & 18 & 71 & 113,4 & 27,75 & 11,6 \\
\hline & Max & 24,7 & 90 & 140 & 29,1 & 15,7 \\
\hline & Mean & 20,17 & 77,86 & 129,37 & 28,35 & 12,96 \\
\hline \multirow{3}{*}{$\begin{array}{l}\text { Gerbillus amoenus } \\
(\mathrm{n}=05)\end{array}$} & Min & 13 & 70 & 101 & 21,41 & 11,48 \\
\hline & Max & 17,95 & 80 & 117 & 23,48 & 13 \\
\hline & Mean & 15,27 & 74,998 & 108,24 & 22,332 & 12,116 \\
\hline
\end{tabular}

$\mathrm{n}$ : number of specimen

Tabla 4. Peso y medidas externas de las especies de roedores registradas en campos de cereal de Taouziant y palmeral de Bouchagroune. Table 4. Weight and external measurements of rodents species recorded in cereal fields of Taouziant and palm grove of Bouchagroune.

Concerning the Shannon index, its values are generally low with 1.68 bits in cereal fields of Taouziant and 1.48 bits in palm grove of Bouchagroune which reflect a moderate diversity of rodent at these two localities. The evenness values at both sites are similar: 0.89 in Taouziant vs 0.88 in Bouchagroune and reflects the same distribution of the rodent in the two localities studied. It tends towards unity so it reflects that the species have a regular distribution (Marcon 2013).

\section{Discussion}

This study is the first in the Aurès region, it provides a new checklist of rodent species and update information about biological known in Ziban region.

Despite an effort of trapping with 2400 nights 
traps, the total number of specimens captured during this study remains intermediate (5.91\%). In a same type of study, the highest rate was obtained in Touggourt area by Hadjoudj et al. (2011) with $5.48 \%$ and the lowest rate is reported in Tiaret region by Adamou-Djerbaoui et al. (2015), with $1.4 \%$. In Beni-Abbes region, Hamdine (2000) trapped a total of 177 rodents for 5815 trap nights (3.04\%). The success of trapping was dependent on the localities studied, which appear to be agricultural zones and which led to the presence of rodents subservient to these environments.

The eight rodent species captured belong into Gerbillinae (four species), Murinae (three species) and Dipodinae (1 species).

The more abundant species were $R$. rattus and $J$. jaculus in cereal fields of Taouziant locality but at palm grove of Bouchagroune site, P. obesus and R. rattus were the most abundant ones, this could reflect differences in aridity and the local presence of Chenopodiaceae that Psammomys favors. Our results of richness at Aurès Mountains (six species) and Ziban (five species) are in general similar to those found by Souttou et al. (2012) in Djelfa region where they report seven species. Also Hadjoudj et al. $(2011,2015)$ shown the similar trapping success and used the same type of traps, which have reported the presence of five species in Touggourt (Saharan region).

Diversity indices provide more information than simply the number of species present. They serve as valuable tools that enable biologists to quantify diversity in a community and describe its numerical structure (Magurran 1988). The most commonly used indices are based on the estimation of relative abundance of species in samples (Heip et al. 1998). The value of the Shannon index obtained in the cereal fields of Taouziant and the palm grove of Bouchagroune is respectively 1.68 bits and 1.48 bits. This value is lower than that found by Souttou et al. (2012) in Djelfa region $(1.81$ bits $)$ perhaps due to area of study (irrigated farm), method of capture and number of specimens.

The Simpson Diversity index illustrates an important number of the species and the Shannon index values indicate a moderate diversity of rodent at these two sites in Aurès Mountains and Ziban oasis. The distribution of specimens over species is equitable.

The specimens of $R$. rattus were caught in the vicinity of the agricultural storehouse in the two studied localities. The species were mentioned by Adamou-Djerbaoui et al. (2015) in the region of Tiaret located in the northwest highlands of Algeria, with 24 specimens. In the palm groves of Touggourt, an Algerian oasis of the Sahara situated at an altitude of 75 MASL, Hadjoudj et al. (2015) trapped 23 specimens. In Morocco, Stoetzel et al. $(2010,2012)$ \& Denys et al. (2015) confirmed the existence of this rodent in central and coastal Morocco.

Concerning the house mouse (M. musculus), its specimens were captured near the agricultural crop storage in the two areas of study. In the semiarid environment, Adamou-Djerbaoui et al. (2015) reported the presence of the species in Tiaret region with 8 specimens, Souttou et al. (2012) note the existence of this rodent in Djelfa $(6,3 \%)$. Badiaf et al. (2013) caught 6 specimens in Djanet region; an extreme southeast of Algeria with an altitude of 1094 MASL. Khammes et al. (2006) found this species in the Kabylie of Djurdjura and in Morocco, Stoetzel et al. (2012) and Denys et al. (2015) reported the presence of this rodent respectively at $9 \%$ and $5 \%$. In this study, we did not find the Algerian mouse Mus spretus Lataste, 1883 , its absence can be conditioned by climatic circumstances and altitude. Khidas et al. (1999) in Kabylie of Djurdjura (northern Algeria) showing that $M$. spretus cannot stand above altitudes more than 700 MASL and that climate is another determining factor of its presence as the mild climate. The cereal fields of the Touaziant region have an altitude above 900 MASL with a cold climate, but the region of the Bouchagroune palm grove has a dry climate. This may justify the absence of $M$. spretus.

R. norvegicus in our inventory was reported only in Khenchela region (Aurès Mountains). Compared to the works reported by AdamouDjerbaoui et al. (2015) the presence of this species was signalled in Tiaret (semi arid region). This author notes its preference for such humid areas. However, Souttou et al. (2012) and Stoetzel et al. (2012) have not noted the presence of this species in the humid areas of their study areas. $M$. shawii was captured in a cereal fields of Taouziant, this rodent is recognized as a pest of crops (Bernard 1970, Adamou-Djerbaoui et al. 2011, 2013). It occurs many crops loss in the High Plateaux of Algerian cereal areas (Adamou-Djerbaoui et al. 2010, 2011,2015, Souttou et al. 2012) were it was recorded in very high proportions 
ranging from: $25.74 \%$ to $68.80 \%$. Sekour et al. (2014) reported the presence of the Shaw's Jird in the Owl's diet in two steppe regions (M'Sila and Djelfa) located on the high plains of Algeria, with a high rate (between $31.90 \%$ and $76.60 \%$ ). In central and coastal Morocco, Stoetzel et al. (2012) and Denys et al. (2015) have reported the presence of this rodent, but in rather low percentage. According to the same authors this is due to the wetter climatic conditions, during their trapping sessions or the use of pesticides. This is the case of cereal fields of Taouziant. J. jaculus was trapped only in Khenchela area. It is a foothill of the Aurès Mountains which presents a stony light soil. According to Shenbrot \& Krasnov (2004) this species is also found in valleys and rocky meadows, but usually prefers flat plains with rare vegetation which explains the high number of catches in the spontaneous zone of Khenchela region. Up to now $P$. obesus was detected in the palm grove of Bouchagroune and Adamou-Djerbaoui et al. (2015) have reported its presence in Tiaret region. Amirat et al. (1977) and Omari et al. (2007) used specimens of $P$. obesus captured in Beni-Abbes region (Bechar departement). Zaime $\&$ Pascal (1988) have reported the presence of the sand rat in Goulimine region southwest of Morocco and Ben Hamou et al. (2006) have reported it in central and southern Tunisia.

G. gerbillus was trapped only in palm grove of Bouchagroune (Biskra region). Souttou et al. (2012), Baddiaf et al. (2013) and Hadjoudj et al. (2015) reported the presence G. gerbillus in their respectively study areas: Djelfa, Djanet and Touggourt. Amirat et al. (1977) used in their research specimens of G. gerbillus from Beni-Abbes region (Bechar department). The geographic range of this species is found throughout the desert and predesert regions of northern Africa (Granjon, 2016).

G. amoenus was captured in many places of Algeria (Kowalski \& Kowalska 1991) and more recently was reported by Souttou et al. (2012), Baddiaf et al. (2013) and Hadjoudj et al. (2015) in Djelfa, Djanet and Touggourt. Zaime \& Pascal (1988); have reported its presence in Morocco. This species has an exclusively North African distribution (Ndiaye et al. 2013).

In the literature, some species have been captured in many areas of Algeria (Hadjoudj et al. 2015, Adamou-Djerbaoui et al. 2015, Kowalski \& Kowalska 1991), but not in our study areas as Meriones lybicus Lichtenstein, 1823, Meriones crassus Sundevall, 1842 and Jaculus orientalis Erxleben, 1777. This can be explained in two ways. The first could be a mediocre efficiency of the baits used (bread, dates) and the low trapping effort. The second, corresponds to very low densities of the species mentioned in the prospected regions (Dobigny 2009).

The study found that both regions were abundant in specific rodent species. $R$. rattus is the most abundant. This state can be related to the important human frequentation and degradation of some habitats. However, P. obesus is the most present species in the palme grove of Bouchagroune; its presence in this region is related by the abundance of $A$. halimus (Chenopodiaceae), while $J$. jaculus was only reported in the cereal fields of Taouziant. The other species are less present in the study sites.

In the Aurès and Ziban region, it would seem that altitude and the arid or semi-arid climate, would be a combination of ecological factors which largely determine the distribution and the diversity of the rodents in Algeria. This ecological barrier would imply possible taxonomic and ecological variations.

Biometric, morphological and genetic measurements are needed to highlight the extent of these variations, their modalities and the possible existence of new subspecies.

\section{References}

Adamou-Djerbaoui M, Djelaila Y, Adamou MS, Baziz B, Nicolas V \& Denys C. 2010. Préférence édaphique et pullulation chez Meriones shawii (Mammalia, Rodentia) dans la région de Tiaret (Algérie). Revue Ecologie (Terre Vie) 65: 63-72.

Adamou-Djerbaoui M, Djelaila Y, Labdelli F \& Adamou MS. 2011. Ecologie et infestation de Meriones shawii Duvernoy dans la région de Tiaret. Revue d'Ecologie et Environnement 7: 7-14.

Adamou-Djerbaoui M, Denys C, Chaba H, Seid MM, Djelaila Y, Labdelli F \& Adamou MS. 2013. Etude du régime alimentaire d'un rongeur nuisible (Meriones shawii Duvernoy, 1842, Mammalia Rodentia) en Algérie. Lebanese Science Journal 14(1): 15-32.

Adamou-Djerbaoui M, Labdelli F, Djelaila Y, Oulbachir K, Adamou MS, \& Denys C. 2015. Inventaire des rongeurs dans la région de Tiaret (Algérie). Travaux de l'Institut Scientifique, Série Générale 8: 105-112.

Amirat A, Khammar F \& Brudieux R. 1977. Variations saisonnières comparées de l'activité sexuelle (données pondérales) chez deux espèces de Rongeurs (Psammomys obesus et Gerbillus gerbillus) du Sahara occidental algérien. Mammalia 41 (3): 341- 
356.

Aulagnier S \& Thevenot M. 1986. Catalogue des mammifères sauvages du Maroc. Travaux de l'Institut Scientifique, série Zoologie, 41, Rabat, Maroc.

Avenant NL \& Cavallini P. 2007. Correlating rodent community structure with ecological integrity, Tussendie-Riviere Nature Reserve, Free State province, South Africa. Integrative zoology 2: 212-219.

Bachar MF \& Belhamra M. 2012. Contribution à l'étude de la dynamique des populations des rongeurs sauvages dans la zone de Biskra. Courrier de Savoir 13: 71-81.

Beddiaf R, Sekour M, Bissati-Bouafia S \& Souttou K. 2013. Inventaire des rongeurs par piégeage direct dans la région de Djanet (Tassili N'ajjer, Sahara centrale). Revue des BioRessources 3(1): 41-49.

Belabbas S \& Butet A. 1994. The diet of the merione, Meriones shawii, in the Nature Reserve of Mergueb, Algeria. Polish Ecoogical Studies 20: 293-303.

Ben Hamou M, Ben Abderrazak S, Frigui S, Chatti N \& Ben Ismail R. 2006. Evidence for the existence of two distinct species: Psammomys obesus and Psammomys vexillaris within the sand rats (Rodentia, Gerbillinae), reservoirs of cutaneous leishmaniasis in Tunisia. Infection, Genetics and Evolution 6: 301-308.

Benredjem W, Leulmi H, Bitam I, Raoult D \& Parola P. 2014. Borrelia garinii and Rickettsia monacensis in Ixodes ricinus Ticks, Algeria. Emerging Infectious Diseases 10(20), 1776-1777.

Bernard J. 1970. Clef de détermination des rongeurs de Tunisie. Extrait des Archives de l'Institut Pasteur de Tunis 47: 265-307.

Bitam I, Rolain JM, Kernif T, Baziz B, Parola P \& Raoult D. 2008. Bartonella species detected in rodents and hedgehogs from Algeria. Journal Compilation 15 (2), 102-103.

Boudrissa A, Cherif K, Kherrachi I, Benbetka S, Bouiba L, Boubidi SC, Benikhlef R, Arrar L, Hamrioui B \& Harrat Z. 2012. Extension de Leishmania major au nord de l'Algérie. Bulletin de la Société de pathologie exotique 105(1): 30-35.

Cherif K, Boudrissa A, Cherif MH \& Harrat Z. 2012. Un programme social pour la lutte physique contre la leishmaniose cutanée zoonotique dans la wilaya de M'Sila en Algérie. Santé Publique 24(6): 511-522.

Couzi L. 2011. Identifier les petits mammifères nonvolants Erinacéomorpha, Soricomorpha, Rodentia d'Aquitaine. Ligue pour la Protection des Oiseaux Aquitaine, Bourdeaux, France.

Denys C, Stoetzel E, Lalis A, Nicolas V, Delapre A, Mataame A, Tifraouine L, Rihane A, El Brini $\mathrm{H}$, Liefrid S, Hafd S, Ouarour A, Cherkaoui A, Fekhaoui A, Benhoussa A, El Hassani A \& Benazzou T. 2015. Inventaire des petits mammifères de milieu anthropisés et naturels du Maroc septentrional. Travaux de I'Institut Scientifique, Série Générale 8: 113-126.

Dobigny G. 2009. Inventaire et Biogéographie des rongeurs du Niger: nuisance aux cultures, implications dans certains problèmes de santé publique et vétérinaire. Archive ouverte des publications scientifiques (HAL).
Dupuy G, Grosbety B \& Dejaifve PA. 2007. Suivi par piégeages de 6 espèces de micromammifères dans la Réserve Naturelle Nationale du Val d'Allier. Direction régional de l'environnement Auvergne, France.

Granjon L \& Duplantier JM. 2009. Les rongeurs Sahélosoudaniens. Institut de Recherche pour le Développement, Marseille, France.

Granjon L. 2016. Gerbillus gerbillus. (errata version published in 2017) The IUCN Red List of Threatened Species. Available at http://dx.doi.org/10.2305/IUCN. UK.2016-3.RLTS.T9123A22463965.en (accessed on 18-XI-2017)

Hadjoudj M, Manaa A, Derdoukh W, Guerzou A, Souttou K, Sekour M \& Doumandji S.2011. Les rongeurs de la région de Touggourt. Actes du Séminaire International sur la Biodiversité Faunistique en Zones Arides et Semi aride, E.N.S.A. Alger :244-251.

Hadjoudj M, Souttou K \& Doumandji S. 2015. Diversity and Richness of Rodent Communities in Various Landscapes of Touggourt Area (Southeast Algeria). Acta Zoologica Bulgarica 67 (3): 415-420.

Hamdine W. 2000. Biosystématique et écologie des populations de Gerbillidés dans les milieux arides, région de Beni Abbès (Algérie). Doctorat d'Etat (Phd Thesis), Faculté Sciences d'Ingénieurs, Université Mouloud Maameri, TiziOuzou, Algérie.

Hamdine W, Khammar F \& Gernigon T. 2006. Distribution des Gerbillidés dans les milieux arides d'El Goléa et de Béni-Abbès (Algérie). Société d'Histoire Naturelle d'Afrique du Nord 73: 45-55.

Heip CHR, Herman PMJ \& Soetaert K. 1998. Indices of diversity and evenness. Océanis 24(4): 61-87.

Hubert B. 1984. Les rongeurs et les problèmes qu'ils posent aux cultures et aux stocks. Laboratoire de Zologie Appliquée de Office de la Recherche Scientifique et Technique Outre-Mer, Dakar, Sénégal.

Khammes N, Lek S \& Aulagnier S. 2006. Identification biométrique des deux espèces sympatriques de souris Mus musculus domesticus et Mus spretus en Kabylie du Djurdjura (Algérie). Revue Suisse de Zoologie 113 (2): 411-419.

Khammes N \& Aulagnier S. 2007. Diet of the Wood mouse, Apodemus sylvaticus, in three biotopes of Kabylie of Djurdjura (Algeria). Folia Zoologica 56(3): 243-252.

Khidas K, Khammes N \& Khelloufi S. 1999. Répartition spatiale et sélection de l'habitat chez le Mulot sylvestre (Apodemus sylvaticus L., 1758) et la Souris sauvage (Mus spretus Lataste, 1883) en Kabylie du Djurdjura (Algérie). Revue Sciences et Technologie 12(2): 59-64.

Kowalski K \& Rzebik-Kowalska B. 1991. Mammals of Algeria. Edition Ossolineum, Wroklaw.

Marcon E. 2013. Mesures de la biodiversité. Ecologie des forêts de Guyane, Unité Mixte de Recherche: CNRS, INRA. Agro Paris Tech \& Cirad.

Magurran AE. 1988. Ecological Diversity and its Measurement. Princeton University Press, Princeton New Jersey, United States of America.

Magurran AE. 2004. Measuring Biological Diversity. Blackwell Science Ltd, Blackwell Publishing Company. 
Malek MA, Hammani A, Beneldjouzi A \& Bitam I. 2014. Enzootic plague foci, Algeria. New Microbe and New Infect 4: 13-16.

Mokrani K, Tebbal S, Raoult D \& Fournier PE 2012. Human rickettsioses in the Batna area, eastern Algeria. Journal homepage 3: 363-365.

Ndiaye A, Shanas U, Chevret P, \& Granjon L. 2013 Molecular variation and chromosomal stability within Gerbillus nanus (Rodentia, Gerbillinae): taxonomic and biogeographic implications. Mammalia 77(1): 105-111.

Omari N, Akli YA, Labrousse F, Delage-Corre M, Le Boutet MJ \& Hadj-Bekkouche F. 2007. Stress nutritionnel chez Psammomys obesus: Physiopathologie de la glande surrénale. Bulletin de la Société zoologique de France 132(3): 163-181.

Sekour M, Souttou K, Guerzou A, Benbouzid N, Guezoul O, Ababsa L, Denys C \& Doumandji S. 2014 Importance de la Mérione de Shaw Meriones shawii au sein des composantes trophiques de la Chouette effraie Tyto alba en milieux steppiques de l'Algérie. Comptes Rendus Biologies 337: 405-415.

Shenbrot G \& Krasnov B. 2004. Temporal dynamics in spatial organization of a rodent community in the Negev Highlands (Israel). Journal of Zoology (London) 263: 207-218.

Singleton GR, Hind LA, Leirs H \& Zhang Z. 1999. Ecologically - based management of rodent pests. Canbe- rra: Australian Centre for International Agricultural Research.

Singleton GR, Hinds LA, Krebs CJ \& Spratt DM. 2003. Rats, mice and people: rodent biology and management. Canberra: Australian Centre for International Agricultural Research.

Souttou K, Sekour M, Gouissem K, Hadjoudj M, Guezoul O, Doumandji S \& Denys C. 2012. Paramètres écologiques des rongeurs dans un milieu semi aride à Djelfa (Algérie). Algérien journal of arid environment 2 (2): 28-41.

Stoetzel E, El Agbani MA, Qninba A, Mouna M, Mataame A, El Brini H \& Denys C. 2010. Inventaire taxonomique préliminaire des petits vertébrés terrestres du Nord du Maroc. Bulletin de l'Institut Scientifique, Rabat, section Sciences de la Vie 32 (1): 1724.

Stoetzel E, Ohler AM, Delapre A, Nicolas V, Jacquet F, Rihane A, Mataame A, Fekhaoui M, Benazzou T \& Denys C. 2012. Inventaire des petits vertébrés terrestres du centre du Maroc. Bulletin de l'Institut Scientifique, Rabat, section Sciences de la Vie 34 (1): 45-56.

Zaime A \& Pascal M. 1988. Essai de validation d'une méthode d'échantillonnage linéaire appliquée à trois espèces de rongeurs d'un peuplement de micromammifères d'un milieu saharien (Guelmine, Maroc). Mammalia 52(2): 258-243. 